\title{
ANALISIS RASIO KEUANGAN UNTUK MENGUKUR KINERJA KEUANGAN PEMERINTAH DAERAH PROVINSI LAMPUNG
}

\author{
Riri Septyaningrum Putri, Deki Fermansyah, Any Eliza, Suharto
}

Universitas Islam Negeri Raden Intan Lampung

Email: rifadaras@gmail.com,dekifermansyah@radenintan.ac.id,anyeliza@ radenintan.ac.id

Abstract: This study aims to determine financial performance based on the ratio approach of effectiveness, independence, and fiscal decentralization in the city of Bandar Lampung. This study uses a qualitative descriptive approach. The data used in this study are secondary data taken through BPKAD Bandar Lampung for the fiscal year 2008-2017. The results of this study indicate that the ratio of regional financial effectiveness on average is at $90.49 \%$ with the effective category and the trend of regional financial effectiveness at 70.814\%; The ratio of regional financial independence average is at $27.96 \%$ which is categorized as low and the trend of regional financial independence is at 262.42\%; while the regional financial fiscal decentralization ratio on average was at $17.85 \%$ with the unfavorable category and the regional financial fiscal decentralization trend was at 197.23\%.

Keywords: Regional Finance, Ratio of Effectiveness, Ratio of Independence, Ratio of Decentralization.

Abstrak: Penelitian ini bertujuan untukmengetahui kinerja keuangan berdasarkan pendekatan rasio efektivitas, kemandirian dan desentralisasi fiscal di kota Bandar Lampung. Penelitian ini menggunakan pendekatan deskriftif kualitatif. Data yang digunakan dalam penelitian ini adalahdata sekunder yang diambil melalui BPKAD kota Bandar Lampung tahun anggaran 2008-2017. Hasil penelitian ini menunjukkan bahwa Rasio efektivitas keuangan daerah secara rata-rata berada pada 90,49\% dengan kategoriefektif dan trend efektivitas keuangan daerah berada pada 70,814\%; Rasio kemandirian keuangandaerah secara rata-rata berada pada $27,96 \%$ dikategorikan rendah dan trend kemandirian keuangan daerah berada pada 262,42\%; sedangkan padarasio desentralisasi fiskal keuangan daerah secara rata-rata berada pada 17,85\% dengan kategori kurang baik dan trend desentralisasi fiskal keuangan daerah berada pada 197,23\% .

Kata Kunci: Keuangan Daerah, Rasio Efektivitas, Rasio Kemandirian, Rasio Desentralisasi.

\section{A. PENDAhuluan}

Era reformasi saat ini memberikan peluang bagi perubahan paradigma pembangunan nasional dari paradigma pertumbuhan menuju paradigma pemerataan pembangunan secara lebih adil dan berimbang. ${ }^{1}$ Untuk melaksanakan tugas sebagai suatu organisasi yang memiliki harta kekayaan yang bersumber dari penerimaan negara yang dipergunakan untuk membiayai segala proses pengurusan, pengelolaan dan penyelenggaraan, hal-hal yang berhubungan dengan proses penerimaan dan pengeluaran negara diatur dalam Undang-Undang Dasar 1945 dan amandemennya. ${ }^{2}$ Menurut UU nomor 32 tahun 2004 yang telah direvisi dengan UU nomor 23 tahun 2014 tentang pemerintah daerah, otonomi daerah adalah hak untuk wewenang dan kewajiban daerah otonom untuk mengatur dan mengurus sendiri urusan pemerintahan dan

${ }^{1}$ DJPK Kemenkeu, "Undang-Undang Nomor 34 Tahun 2000 Tentang Perubahan Pajak Atas UndangUndang Republik Indonesia No.18 Tahun 1997 Tentang Pajak Dan Retribusi Daerah," Lihat: Www.Djpk.Kemenkeu.Go.Id.

${ }^{2}$ Munawir Sazali, "Implementasi Pengelolaan Keuangan Negara Dalam Perspektif Ekonomi Islam (Studi APBN 2009-2017),” Al-Intaj: Jurnal Ekonomi dan Perbankan Syariah 6, no. 2 (2020), hlm. 88-107. 
kepentingan masyarakat setempat dalam sistem Negara Kesatuan Republik Indonesia. ${ }^{3}$ Adapun misi utama UU nomor 33 tahun 2004 adalah bukan hanya untuk melimpahkan kewenangan pembangunan dari pemerintah pusat ke pemerintah daerah tetapi yang lebih penting adalah efisiensi dan efektivitas sumber daya keuangan. ${ }^{4}$

Sejak diberlakukannya Undang-Undang No.22 tahun 1999, tentang pelaksanaan otonomi daerah, maka terjadi perubahan yang mendasar dalam pengelolaan keuangan daerah. Otonomi daerah adalah wewenang yang dimiliki daerah otonom untuk mengatur dan mengurus masyarakatnya menurut kehendak sendiri berdasarkan aspirasi masyarakat, sesuai dengan peraturan UU yang berlaku. ${ }^{5}$ Ciri utama yang menunjukkan suatu daerah otonom mampu berotonomi terletak pada kemampuan keuangan daerahnya. Artinya daerah otonom harus memiliki kewenangan dan kemampuan untuk menggali sumber-sumber keuangan sendiri, sedangkan ketergantungan pada bantuan pemerintah pusat harus seminimal mungkin, sehingga PAD harus menjadi bagian sumber keuangan terbesar yang didukung oleh kebijakan pembagian keuangan pusat dan daerah sebagai prasyarat mendasar sistem pemerintahan negara. Konsekuensi dari penerapan otonomi daerah yaitu setiap daerah dituntut untuk meningkatkan pendapatan asli daerah (PAD) guna membiayai urusan rumah tangganya sendiri. ${ }^{6}$

APBD merupakan rencana keuangan tahunan pemerintahan daerah yang dibahas dan disetujui bersama oleh pemerintah Daerah dan Dewan Perwakilan Rakyat, dan ditetapkan dengan peraturan daerah $)^{7}$. Berdasarkan penerapan otonomi daerah maka pemerintah daerah yang menentukan Anggaran tersebut, sesuai dengan kebutuhan dan potensi daerah serta arah pembangunan daerah tersebut. Dengan dikelolanya APBD oleh pemerintah daerah masingmasing tanpa ada campur tangan pemerintah pusat dalam rangka perwujudan otonomi daerah atau desentralisasi fiskal. ${ }^{8}$

Salah satu faktor yang mempengaruhi proses penyelenggaraan pemerintah daerah adalah dari segi faktor keuangan. Kota Bandar Lampung merupakan Ibukota di Provinsi Lampung dan salah satu kota yang memiliki pendapatan yang selalu meningkat dibandingkan kota atau kabupaten lain yang ada di Provinsi Lampung. Kota Bandar lampung menduduki posisi pertama di Provinsi Lampung sebagai kota yang mendapatkan Pendapatan Asli Daerah (PAD) yang besar dibandingkan kabupaten/ kota yang ada di Provinsi Lampung.

Alasannya peningkatan Pendapatan Asli Daerah (PAD) Kota Bandar Lampung selalu diikuti dengan jumlah dana berimbang yang selalu meningkat. Daerah otonom harus seminim mungkin ketergantungan pada bantuan pemerintah pusat dan Pendapatan Asli Daerah(PAD) harus menjadi bagian sumber keuangan terbesar. Berikut ini adalah Pendapatan Asli Daerah (PAD) dikota/kabupaten di Provinsi Lampung:

\footnotetext{
${ }^{3}$ I Bisma, Dewa Gde, and Hery Susanto, "Evaluasi Kinerja Keuangan Daerah Pemerintah Provinsi Nusa Tenggara Barat Tahun Anggaran 2003-2007," Ganec Swara 4, no. 3 (2010), hlm. 75-86.

${ }^{4}$ Ibid.

${ }^{5}$ Joko Pramono, “Analisis Rasio Keuangan Untuk Menilai Kinerja Keuangan Pemerintah Daerah (Studi Kasus Pada Pemerintah Kota Surakarta)," Among Makarti 7, no. 1 (2014).

${ }^{6}$ Aswarodi, "Analisis Perimbangan Keuangan Pusat Dan Daerah Sebelum Dan Setelah Pemberlakuan Undang -Undang No. 25 Tahun 1999 Di Kabupaten Lampung Selatan,” in Bunga Rampai Manajemen Keuangan Daerah (Yogyakarta: UPP AMP YKPN, 2004).

${ }^{7}$ Republik Indonesia, "Undang-Undang Republik Indonesia Nomor 33 Tahun 2004 Tentang," Perimbangan Keuangan antara Pemerintah Pusat dan Pemerintah Daerah (2004).

${ }^{8}$ Rahardjo Adisasmita, Pembiayaan Pembangunan Daerah (Yogyakarta: Graha Ilmu, 2011), hlm. 41.
} 
Tabel 1. Pendapatan Asli Daerah Kabupaten/Kota Provinsi Lampung Tahun 2008-2016

(Dalam Miliar Rupiah)

\begin{tabular}{|c|c|c|c|c|c|c|c|c|c|}
\hline \multirow{2}{*}{$\begin{array}{c}\text { Kabupaten/ } \\
\text { Kota }\end{array}$} & \multicolumn{9}{|c|}{ Tahun } \\
\hline & 2008 & 2009 & 2010 & 2011 & 2012 & 2013 & 2014 & 2015 & 2016 \\
\hline Bandar Lampung & 67.661 & 70.432 & 86.692 & 162.818 & 298.696 & 360.968 & 394.646 & 397.547 & 483.379 \\
\hline Metro & 19.980 & 21.060 & 27.345 & 42.002 & 48.377 & 59.224 & 97.307 & 127.586 & 113.989 \\
\hline Lampung Barat & 17.198 & 11.579 & 16.302 & 21.562 & 25.278 & 33.829 & 40.800 & 46.434 & 49.078 \\
\hline Tanggamus & 15.314 & - & 11.663 & 26.258 & 18.672 & 22.017 & 22.488 & 21.979 & 23.712 \\
\hline Lampung Selatan & 25.572 & 25.030 & 40.749 & 68.652 & 80.459 & 100.050 & 130.597 & 161.645 & 184.063 \\
\hline Lampung Timur & 26.645 & 18.821 & 20.669 & 31.844 & 49.824 & 40.761 & 83.131 & 84.496 & 94.924 \\
\hline Lampung Tengah & 22.837 & 24.471 & 37.086 & 50.591 & 101.060 & 81.780 & 108.180 & 116.343 & 137.871 \\
\hline Lampung Utara & 16.531 & 11.794 & 13.499 & 28.762 & 21.351 & 46.626 & 80.918 & 93.239 & 98.607 \\
\hline Way Kanan & 14.476 & 11.481 & 8.745 & 9.472 & 10.148 & 24.831 & 45.811 & 47.882 & 44.346 \\
\hline Tulang Bawang & 10.437 & 11.396 & 44.498 & 19.980 & 23.152 & 36.242 & 24.444 & 34.008 & 26.416 \\
\hline Pesawaran & 2.825 & 4.542 & 13.229 & $17 \mathrm{~S} .916$ & 25.710 & 25.933 & 36.482 & 37.060 & 41.956 \\
\hline Pringsewu & - & - & 5.809 & 19.347 & 29.090 & 30.421 & 63.339 & 61.765 & 68.157 \\
\hline Mesuji & - & - & 1.398 & 5.392 & 8.269 & 10.021 & 20.901 & 18.713 & 27.783 \\
\hline $\begin{array}{c}\text { Tulang Bawang } \\
\text { Barat }\end{array}$ & - & - & 2.214 & 4.298 & 5.840 & 10.345 & 15.436 & 16.452 & 20.882 \\
\hline Pesisir Barat & - & - & - & - & - & - & 10.373 & 11.597 & 20.710 \\
\hline
\end{tabular}

Sumber : Badan Pendapatan Keuangan dan Aset Daerah Tahun 2018.

Peningkatan Pendapatan Asli Daerah (PAD) Kota Bandar Lampung selalu diikuti dengan jumlah Dana Perimbangan yang selalu meningkat. Dana berimbang merupakan sumber pendapatan daerah yang berasal dari APBN untuk mendukung pelaksanaan kewenangan pemerintahan daerah dalam mencapai tujuan pemberian otonomi kepada daerah. ${ }^{10}$ Berikut ini adalah dana Berimbang kota Bandar Lampung:

Tabel 2. Dana Berimbang Kota Bandar Lampung

Tahun 2008-2017

\begin{tabular}{|c|r|r|r|}
\hline Tahun & PAD & Dana Berimbang & \multicolumn{1}{c|}{$\begin{array}{c}\text { Lain-lain PAD } \\
\text { yang sah }\end{array}$} \\
\hline 2008 & $67.661 .519 .021,92$ & $634.760 .315 .000,46$ & $7.896 .232 .000,43$ \\
\hline 2009 & $70.432 .26 .0003,19$ & $659.733 .381 .000,20$ & $4.460 .818 .000,96$ \\
\hline 2010 & $86.692 .399 .700,41$ & $672.078 .484 .000,49$ & $4.704 .103 .000,83$ \\
\hline 2011 & $162.818 .119 .556,88$ & $747.009 .425 .171,00$ & $6.198 .579 .220,88$ \\
\hline 2012 & $298.696 .062 .085,49$ & $901.841 .182 .094,00$ & $40.144 .717 .721,23$ \\
\hline 2013 & $360.698 .350 .131,88$ & $992.894 .943 .895,00$ & $59.158 .057 .632,84$ \\
\hline 2014 & $394.646 .889 .446,59$ & $1.039 .433 .426 .630,00$ & $89.351 .963 .991,40$ \\
\hline 2015 & $397.547 .326 .856,39$ & $1.016 .422 .749 .268,00$ & $81.159 .929 .433,12$ \\
\hline 2016 & $483.379 .398 .034,84$ & $1.376 .175 .794 .387,00$ & $98.172 .277 .364,71$ \\
\hline 2017 & $612.809 .680 .623,87$ & $1.456 .610 .360 .061,45$ & $197.725 .452 .250,52$ \\
\hline
\end{tabular}

Sumber : Badan Pendapatan Keuangan dan Aset Daerah Tahun 2008-2017."

\footnotetext{
${ }^{10}$ Deddy Supriady Bratakusumah, Otonomi Penyelenggaraaan Pemerintahan Daerah, (Gramedia Pustaka Utama, 2001), hlm. 174.

${ }^{11}$ BPKAD, Laporan Keuangan Kota Bandar Lampung Tahun 2008-2017, (Pemerintah Kota Bandar Lampung, 2017 hlm. 86.
}

(2018).

${ }^{9}$ Badan Pusat Statistik Provinsi Lampung, Pendapatan Asli Daerah Kota Bandar Lampung 2008-2016, 
Berdasarkan Tabel 2 dapat dilihat bahwa dana berimbang pada tahun 2008-2017 Kota Bandar Lampung selalu mengalami peningkatan. Dilihat besarnya dana berimbang dibandingkan dengan pendapatan asli daerah (PAD) mengindikasikan masih rendahnya kemandirian akibat ketergantungan fiskal pemerintah Kota Bandar Lampung terhadap pemerintah pusat selama kurun waktu 2008-2017.

Besarnya dana berimbang dibandingkan dengan pendapatan asli daerah (PAD) mengindikasikan masih rendahnya kemandirian akibat ketergantungan fiskal pemerintah Kota Bandar Lampung terhadap pemerintah pusat selama kurun waktu 2008-2017. Hal ini sesuai dengan teori yang dikemukakan oleh Abdul Halim dalam Reza Marizka bahwa kemandirian keuangan daerah ditunjukkan oleh besar kecilnya pendapatan asli daerah (PAD) dibandingkan dengan pendapatan daerah yang berasal dari sumber lain seperti bantuan pemerintah pusat ataupun dari pinjaman. ${ }^{12}$ Tingkat kemandirian, efektivitas, dan desentralisasi keuangan daerah pemerintah/kota dalam pengelolaan dana yang diperoleh tersebut dapat mencerminkan kinerja pemerintahannya.

Kinerja (performance) adalah gambaran mengenai tingkat pencapaian pelaksanaan suatu kegiatan/program/kebijakan dalam mewujudkan sasaran, tujuan, visi dan misi organisasi yang tertuang dalam strategik planning. Kinerja bisa diketahui hanya jika individu maupun kelompok individu tersebut mempunyai kriteria keberhasilan yang telah ditetapkan.13

Dalam rangka Pengelolaan Keuangan Daerah perlu dilakukanlah analisis rasio keuangan untuk menilai kinerja Pemerintahan Daerah yaitu analisis rasio efektivitas, rasio kemandirian dan rasio desentralisasi fiskal. Rasio efektivitas menggambarkan kemampuan pemerintah dalam merealisasikan Pendapatan Asli Daerah (PAD) yang direncanakan dibandingkan dengan target yang ditetapkan berdasarkan potensi rill. Rasio kemandirian menunjukkan kemampuan keuangan daerah dalam membiayai sendiri kegiatan pemerintah, pembangunan, dan pelayanan kepada masyarakat.14

Penelitian yang dilakukan oleh Dori (2014) menunjukan bahwa kemandirian keuangan masih tergantung pada adanya bantuan dari pusat.15 Lebih lanjut berdasarkan hasil penelitian Andry (2014) menunjukan bahwa rasio efektivitas keuangan daerah kota Medan menujukan penurunan pada trend rasio efektivitas, namun desentralisasi menunjukan kemampuan yang cukup baik.16

Berdasarkan uraian tersebut, maka tujuan dari penelitian ini adalah untuk mengetahui kinerja keuangan yang dilihat berdasarkan rasio efektivitas, rasio kemandirian dan rasio desentralisasi fiskal di Kota Bandar Lampung.

\footnotetext{
${ }^{12}$ Reza Marizka, Pengaruh Pendapatan Asli Daerah, Dana Bagi Hasil, Dana Alokasi Umum, Dan Dana Alokasi Khusus Terhadap Tingkat Kemandirian Keuangan Daerah Pada Kabupaten Dan Kota Di Sumatera Barat Tahun 2006-2011 (Padang: Universitas Negeri Padang, 2014), hlm. 3.

${ }^{13}$ Paramitha Sandy Mokodompit, Sifrid S Pangemanan, and Inggriani Elim, “Analisis Kinerja Keuangan Pemerintah Daerah Kota Kotamobagu," Jurnal EMBA: Jurnal Riset Ekonomi, Manajemen, Bisnis dan Akuntansi 2 , no. 2 (2014).

${ }^{14}$ Andri Haryanto, Analisis Efektivitas, Kemandirian Dan Desentralisasi Pemerintah Kota Medan (Medan: Universitas Muhammadiyah Sumatera Utara, 2014), hlm. 22.

${ }^{15}$ Dori Saputra, Analisis Kemandirian Dan Efektivitas Keuangan Daerah Pada Kabupaten Dan Kota Di Provinsi Sumatera Barat (Padang: Universitas Negeri Padang, 2014).

${ }^{16}$ Haryanto, Analisis Efektivitas, Kemandirian Dan Desentralisasi Pemerintah Kota Medan.
} 


\section{B. METODE PENELITIAN}

Penelitian ini menggunakan metode pendekatan deskriptif kuantitatif. Penelitian deskriptif dalam penelitian ini untuk menggambarkan dan menganalisis kemampuan daerah serta kinerja keuangan pemerintah Kota Bandar Lampung yang diukur melalui analisis rasio yaitu rasio efektivitas, rasio kemandirian, dan rasio desentralisasi fiskal.

Metode pengumpulan data dalam penelitian ini menggunakan metode dokumentasi dan studi pustaka. Sumber data yang digunakan dalam penelitian ini adalah data sekunder berupa data APBD tahun 2008-2017 yang didapatkan dari BPKAD kota Bandar Lampung tahun anggaran 2008-2017. Populasi dalam penelitian ini adalah Anggaran Pendapatan dan Belanja Daerah (APBD). Sampel dalam penelitian ini adalah Anggaran Pendapatan dan Belanja Daerah (APBD) dalam 10 tahun dari tahun 2008-2017.

Metode analisis yang digunakan adalah dengan menggunakan analisis rasio. Analisis rasio yang digunakan ada tiga yaitu rasio efektivitas, rasio kemandirian dan rasio desentralisasi fiskal.

Rasio efektivitas keuangan daerah otonom (selanjutnya disebut "Rasio EKD") menggambarkan kemampuan pemerintah daerah merealisasikan pendapatan asli daerah yang direncanakan dibandingkan dengan target yang telah ditetapkan berdasarkan potensi riil daerah. ${ }^{17}$ Berikut merupakan perhituangan rasio efektivitas keuangan daerah: ${ }^{18}$

$$
\text { Rasio Efektivitas }=\frac{\text { Realisasi Penerimaan PAD }}{\text { Target Penerimaan PAD }} \times 100
$$

Tabel 3. Kriteria Efektivitas Keuangan Daerah

\begin{tabular}{|l|l|}
\hline \multicolumn{1}{|c|}{ Rasio Efektivitas } & \multicolumn{1}{c|}{ Persentase (\%) } \\
\hline Sangat Efektif & $>100$ \\
\hline Efektif & $>90-100$ \\
\hline Cukup Efektif & $>80-90$ \\
\hline Kurang Efektif & $>60-80$ \\
\hline
\end{tabular}

Sumber : Depdagri, Kepmendagri tahun 2002. ${ }^{19}$

Selanjutnya Trend efektivitas keuangan daerah penting dinilai untuk mengetahui arah perkembangan dimensi efektivitas keuangan daerah. Suatu daerah otonom kabupaten/kota pada suatu tahun tertentu barangkali belum dapat memenuhi efektivitas keuangannya, tetapi dengan melihat trend positif dari kedua dimensi keuangan tersebut diperoleh keyakinan, walaupun lambat ada peluang akan menuju efektivitas keuangan daerah yang ideal. Analisis trend efektivitas keuangan daerah digunakan untuk mengetahui arah perkembangan efektivitas keuangan daerah tersebut. Apabila persentase trend EKD lebih dari 100\%, maka telah terjadi perkembangan EKD. Semakin besar persentase trend EKD dari tahun ke tahun maka arah perkembangan efektivitas keuangan daerah di Kota Bandar Lampung. Sebaliknya, bila

\footnotetext{
${ }^{17}$ Abdul Halim, Akuntansi Keuangan Daerah (Jakarta: Salemba Empat, 2008).

${ }^{18}$ Saputra, "Analisis Kemandirian Dan Efektivitas Keuangan Daerah Pada Kabupaten Dan Kota Di Propinsi Sumatera Barat, Jurnal Akuntansi, 2014"

${ }^{19}$ Keputusan Menteri Dalam Negeri Nomor, "Tahun 2002 Tentang Pedoman Pengurusan," Pertanggungjawaban Dan Pengawasan Keuangan Daerah Serta Tata Cara Penyusunan Anggaran Pendapatan Dan Belanja Daerah, Pelaksanaan Tata Usaha Keuangan Daerah Dan Penyusunan Perhitungan Anggaran Pendapatan Dan Belanja Daerah (29AD).
} 
persentase kurang dari $100 \%$ maka terjadi penurunan efektivitas keuangan Perhitungan trend efektivitas keuangan daerah di Kota Bandar Lampung.

Dalam penelitian ini, tahun 2008 merupakan tahun dasar yang akan digunakan sebagai tahun dasar untuk melihat arah perkembangan EKD pada tahun berikutnya (Tahun 2009 sampai dengan 2017). Dengan demikian, trend yang diperoleh nanti dapat diinterpretasikan sebagai arah perkembangan yang terjadi dengan diimplementasikannya reformasi otonomi dan keuangan daerah.

$$
\text { Trend } \mathrm{EKD}=\frac{\text { EKD Tahun Pembanding }}{\text { EKD Tahun Dasar }} \times 100
$$

Rasio kemandirian keuangan daerah (selanjutnya disebut "Rasio KKD”) menunjukkan kemampuan pemerintah daerah dalam membiayai sendiri kegiatan pemerintahan, pembangunan, dan pelayanan kepada masyarakat yang telah membayar pajak dan retribusi sebagai sumber pendapatan yang diperlukan daerah ${ }^{20}$, yang dapat diformulasikan sebagai berikut:

$$
\text { Trend } \mathrm{EKD}=\frac{\text { EKD Tahun Pembanding }}{\text { EKD Tahun Dasar }} \times 100
$$

Berdasarkan formula di atas dapat diketahui bahwa rasio KKD menggambarkan sejauh mana ketergantungan daerah terhadap sumber dana ekstern. Semakin tinggi rasio ini berarti tingkat ketergantungan daerah terhadap bantuan pihak ekstern (terutama pemerintah pusat dan propinsi) semakin rendah, demikian pula sebaliknya. ${ }^{21}$ Rasio ini juga menggambarkan tingkat partisipasi masyarakat dalam pembangunan daerah. Semakin tinggi rasio ini berarti semakin tinggi partisipasi masyarakat dalam membayar pajak dan retribusi daerah yang merupakan komponen dari Pendapatan Asli Daerah (PAD).

Tabel 4. Pola Hubungan dan Kriteria Tingkat Kemandirian Keuangan Daerah

\begin{tabular}{|l|l|l|}
\hline $\begin{array}{c}\text { Kemampuan / } \\
\text { Ketergantungan } \\
\text { Keuangan Daerah }\end{array}$ & \multicolumn{1}{|c|}{ Persentase } & $\begin{array}{c}\text { Pola } \\
\text { Hubungan }\end{array}$ \\
\hline Rendah Sekali & $0 \%-25 \%$ & Instruktif \\
\hline Rendah & $25 \%-50 \%$ & Konsultatif \\
\hline Sedang & $50 \%-75 \%$ & Partisipatif \\
\hline Tinggi & $75 \%-100 \%$ & Delegatif \\
\hline
\end{tabular}

Sumber : Depdagri, Kepmendagri No. 29 tahun 2002. ${ }^{22}$

Selanjutnya Kecenderungan kemandirian keuangan daerah penting dinilai untuk mengetahui arah perkembangan kedua dimensi keuangan ini. Suatu daerah otonom kabupaten/kota pada suatu tahun tertentu barangkali belum dapat memenuhi kemandirian keuangannya, tetapi dengan melihat trend positif dari dimensi kemandirian keuangan tersebut diperoleh keyakinan, walaupun lambat ada peluang akan menuju kemandirian keuangan daerah yang ideal. Analisis trend kemandirian keuangan daerah digunakan untuk mengetahui arah

\footnotetext{
${ }^{20}$ Maisyuri Maisyuri, “Analisis Kinerja Keuangan Daerah Pemerintah Kota Lhokseumawe,” Jurnal Visioner \& Strategis 6, no. 1 (2017).

${ }^{21}$ Ikhwani Ratna, “Analisis Kinerja Keuangan Daerah Dan Strategi Pembangunan Kota Di Era Otonomi Daerah Pada Kota Pekanbaru,” Jurnal El-Riyasah 3, no. 1 (2012), hlm. 1-10.

${ }^{22}$ Nomor, "Tahun 2002 Tentang Pedoman Pengurusan."
} 
perkembangan kemandirian keuangan daerah tersebut. Apabila persentase trend KKD lebih dari $100 \%$, maka telah terjadi perkembangan KKD. Semakin besar persentase trend KKD dari tahun ke tahun maka arah perkembangan kemandirian keuangan di Kota Bandar Lampung semakin baik. Sebaliknya, bila persentase kurang dari 100\% maka terjadi penurunan kemandirian keuangan kabupaten/kota.

Dalam penelitian ini, tahun 2008 merupakan tahun dasar yang akan digunakan sebagai tahun dasar untuk melihat arah perkembangan KKD pada tahun berikutnya (tahun 2009 sampai dengan 2017). Dengan demikian, trend yang diperoleh nanti dapat diinterpretasikan sebagai arah perkembangan Perhitungan trend kemandirian keuangan daerah yang terjadi dengan diimplementasikannya reformasi otonomi dan keuangan daerah.Dari penjelasan ini maka trend kemandirian keuangan daerah dapat diformulasikan sebagai berikut:

$$
\text { Trend } \mathrm{KKD}=\frac{\text { KKD Tahun Pembanding }}{\text { KKD Tahun Dasar }} \times 100
$$

Rasio desentralisasi fiskal merupakan kemampuan pemerintah daerah dalam menjalankan kewenangan atau tanggung jawab yang diberikan pemerintah pusat kepada pemerintah daerah untuk menggali dan mengelola pendapatan. Perhitungan desentralisasi fiskal:

$$
\text { Rasio Desentralisasi }=\frac{\text { Total Pendapatan Asli Daerah }}{\text { Total Pendapatan Daerah }} \times 100
$$

Tabel 5. Tingkat Desentralisasi Fiskal Keuanga
\begin{tabular}{|c|c|}
\hline $\begin{array}{c}\text { Kemampuan keuangan } \\
\text { daerah }\end{array}$ & $\begin{array}{c}\text { Desentralisasi } \\
\%\end{array}$ \\
\hline Sangat kurang & $0,00-10,0 \%$ \\
\hline Kurang & $10,01-20,00 \%$ \\
\hline Sedang & $20,01-30,00 \%$ \\
\hline Cukup & $30,01-40,00 \%$ \\
\hline Baik & $40,01-50,00 \%$ \\
\hline
\end{tabular}

Sumber : Depdagri, Kepmendagri No. 29 tahun $2002 .^{23}$

Selanjutnya analisis trend desentralisasi keuangan daerah digunakan untuk mengetahui arah perkembangan kemampuan pemerintah daerah memaksimalkan tanggung jawab yang diberikan. Semakin besar persentase trend desentralisasi dari tahun ke tahun maka arah perkembangan kemampuan pemerintah/kota dalam menggali potensi. daerahnya semakin baik dan sebaliknya. ${ }^{24}$ Perhitungan trend desentralisasi fiskal:

$$
\text { Trend } \mathrm{DKD}=\frac{\text { DKD Tahun Pembanding }}{\text { DKD Tahun Dasar }} \times 100
$$

\section{HASIL DAN PEMBAHASAN}

Berdasarkan data yang diperoleh diharapkan dapat diketahui bagaimana kinerja keuangan daerah khususnya di Kota Bandar Lampung tahun 2008-2017 berdasarkan 3 rasio

\footnotetext{
${ }^{23}$ Ibid.

${ }^{24}$ Haryanto, Analisis Efektivitas, Kemandirian, Dan Desentralisasi Pemerintah Kota Medan, Medan: Universitas Muhammadiyah Sumatera Utara, 2014), hlm. 23.
} 
yaitu rasio efektivitas, rasio kemandirian dan rasio desentralisasi fiskal. Dengan analisis rasio keuangan pemerintah daerah dapat menilai kemandirian keuangan daerah, mengukur efektivitas keuangan daerah, dalam merealisasikan pendapatan asli daerah, dan dapat mengukur masing masing sumber pendapatan dalam membentuk pendapatan daerah.

\section{Analisis Rasio Efektivitas}

Rasio efektivitas dapat dihitung dengan cara membandingkan antara realisasi penerimaan pendapatan asli daerah (PAD) dengan target penerimaan pendapatan asli daerah (PAD). Berdasarkan rasio efektivitas keuangan daerah pemerintah Kota Bandar Lampung pada tahun 2008-2017 dapat dilihat pada Tabel 6 :

Tabel 6. Rasio Efektivitas Keuangan Daerah Kota Bandar Lampung Tahun 2008-2017

\begin{tabular}{|c|c|c|c|c|}
\hline Tahun & Target (Rp) & Realisasi (Rp) & $\begin{array}{c}\text { Rasio } \\
\text { Efektivitas } \\
(\boldsymbol{\%})\end{array}$ & $\begin{array}{c}\text { Trend } \\
\text { Efektivitas } \\
(\boldsymbol{\%})\end{array}$ \\
\hline 2008 & $60.422 .775 .028,70$ & 67.661 .519 .021 .92 & 111,98 & 100 \\
\hline 2009 & $72.009 .309 .841,70$ & $70.432 .260 .003,19$ & 97,81 & 87,35 \\
\hline 2010 & $75.031 .991 .782,16$ & $86.692 .399 .700,41$ & 115,54 & 103,18 \\
\hline 2011 & $156.796 .491 .183,50$ & $162.818 .119 .556,88$ & 103,84 & 92,73 \\
\hline 2012 & $292.272 .049 .972,25$ & $298.696 .062 .085,49$ & 102,20 & 91,27 \\
\hline 2013 & $418.111 .740 .815,52$ & $360.698 .350 .131,88$ & 86,27 & 77,04 \\
\hline 2014 & $495.200 .463 .391,26$ & $394.646 .889 .446,59$ & 79,69 & 71,16 \\
\hline 2015 & $769.108 .142 .606,24$ & $397.547 .326 .856,39$ & 51,69 & 46,16 \\
\hline 2016 & $757.745 .187 .987,05$ & $483.379 .398 .034,84$ & 63,79 & 56,97 \\
\hline 2017 & $994.795 .696 .600,00$ & $612.809 .680 .623,87$ & 92,14 & 82,28 \\
\hline $\begin{array}{c}\text { Rata- } \\
\text { rata }\end{array}$ & $\mathbf{4 0 9 . 1 4 9 . 3 8 4 . 9 2 0 , 8 4}$ & $\mathbf{2 9 3 . 5 3 8 . 2 0 0 . 5 4 6 , 1 5}$ & $\mathbf{9 0 , 4 9 5}$ & $\mathbf{7 0 , 8 1 4}$ \\
\hline
\end{tabular}

Sumber: Data diolah, 2018

Berdasarkan Tabel 6 tersebut pada tahun 2010 merupakan yang tertinggi selama tahun 2008-2017 karena rasio efektivitas keuangan daerah yang dicapai melebihi 100 persen atau sebesar 115,54 persen sebagaimana berdasarkan kriteria kinerja keuangan efektivitas keuangan daerah dimana lebih dari 100 persen merupakan kriteria sangat efektif. Pada tahun 2015 kemampuan pemerintah daerah dalam merealisasikan pendapatan asli daerah (PAD) yang telah di anggarkan tidak efektif dan merupakan yang terendah selama tahun 2008-2017 karena rasio efektivitas keuangan daerah kurang dari 60 persen atau sebesar 51,69 persen. Dari tabel 6 di atas dapat dibuat gambar efektivitas keuangan daerah sebagaimana dilihat pada gambar 1 berikut:

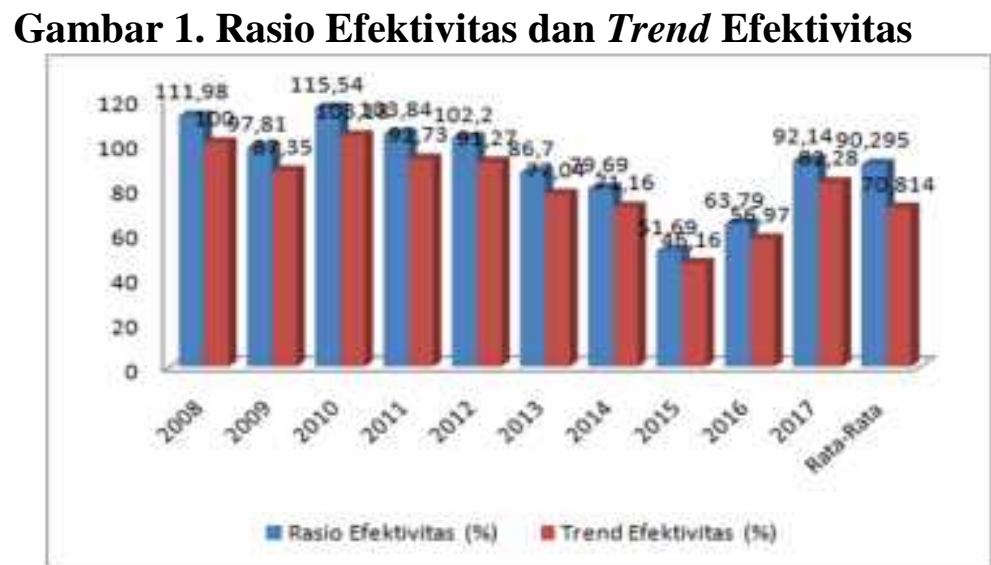

Sumber: Data diolah, 2018 
Dilihat dari data di atas menggambarkan bahwa rasio efektivitas keuangan daerah mengalami peningkatan dan penurunan. Secara rata-rata rasio efektivitas selama tahun 20082017 merupakan kriteria efektif dengan persentase sebesar 90,495 persen sebagaimana berdasarkan kriteria kinerja keuangan efektivitas keuangan daerah dimana 90-100 persen dalam kriteria efektif. Kemudian untuk melihat perkembangan efektivitas keuangan daerah tahun 2008-2017 diukur menggunakan trend dengan tahun 2008 sebagai tahun dasar.

Trend efektivitas keuangan daerah tahun 2008-2017 mengalami banyak penurunan dengan rata-rata trend efektivitas sebesar 70,81 persen. tahun 2010 merupakan persentase tertinggi karena trend efektivitas keuangan daerah mencapai lebih dari 100 persen atau sebesar 103,18 persen. Dan pada tahun 2015 merupakan persentase terendah sebesar 46,16 persen menunjukan perkembangan efektivitas keuangan daerah yang menurun atau kurang baik.

Pemerintah Kota Bandar Lampung sudah berupaya menerapkan potensi yang sebenarnya tetapi masih banyak kendala sehingga tidak mencapai target yang telah ditentukan seperti dalam hal pemungutan pajaknya yang mempengaruhi pendapatan asli daerah di Kota Bandar Lampung yaitu kemampuan sumber daya manusia yang masih kurang, sarana prasarana yang belum maksimal, tingkat kesadaran dari wajib pajak masih sangat kurang, masih kurang maksimalnya sanksi bagi wajib pajak yang belum melakukan pembayaran pajak dalam bentuk sanksi administrasi maupun sanksi pidanasesuai dengan peraturan pada Undang-Undang 28 dan dilihat dari kondisi ekonomi di Kota Bandar Lampung, daya beli masyarakatnya juga ikut mempengaruhi. Jika daya beli masyarakat naik pendapatan restoran hotel atau bisnis lainnya akan ikut naik sehingga mereka bisa membayar pajaknya.

\section{Analisis Rasio Kemandirian}

Rasio kemandirian dapat dihitung dengan cara membandingkan antara realisasi penerimaan Pendapatan Asli Daerah (PAD) dengan target bantuan pemerintah pusat. Berdasarkan rasio kemandirian keuangan daerah pemerintah Kota Bandar Lampung pada tahun 2008-2017 dapat dilihat pada Tabel 7:

Tabel 7. Rasio Kemandirian Keuangan Daerah Kota Bandar Lampung Tahun 2008-2017

\begin{tabular}{|c|c|c|c|c|}
\hline Tahun & PAD (Rp) & $\begin{array}{c}\text { Pendapatan } \\
\text { Transfer }(\mathbf{R p})\end{array}$ & $\begin{array}{c}\text { Rasio } \\
\text { Kemandirian } \\
(\mathbf{\%})\end{array}$ & $\begin{array}{c}\text { Trend } \\
\text { Kemandirian } \\
(\mathbf{\%})\end{array}$ \\
\hline 2008 & 67.661 .519 .021 .92 & $634.760 .315 .000,46$ & 10,66 & 100 \\
\hline 2009 & $70.432 .260 .003,19$ & $659.733 .381 .000,20$ & 10,68 & 100,19 \\
\hline 2010 & $86.692 .399 .700,41$ & $672.078 .484 .000,49$ & 12,90 & 121,01 \\
\hline 2011 & $162.818 .119 .556,88$ & $747.009 .425 .171,00$ & 21,80 & 204,50 \\
\hline 2012 & $298.696 .062 .085,49$ & $901.841 .182 .094,00$ & 33,12 & 310,69 \\
\hline 2013 & $360.698 .350 .131,88$ & $992.894 .943 .895,00$ & 36,23 & 340,81 \\
\hline 2014 & $394.646 .889 .446,59$ & $1.039 .433 .426 .630,00$ & 37,97 & 356,19 \\
\hline 2015 & $397.547 .326 .856,39$ & $1.016 .422 .749 .268,00$ & 39,11 & 366,89 \\
\hline 2016 & $483.379 .398 .034,84$ & $1.376 .175 .794 .387,00$ & 35,12 & 329,36 \\
\hline 2017 & $612.809 .680 .623,87$ & $1.456 .610 .360 .061,45$ & 42,07 & 394,65 \\
\hline $\begin{array}{c}\text { Rata- } \\
\text { Rata }\end{array}$ & $\mathbf{2 9 3 . 5 3 8 . 2 0 0 . 5 4 6 , 1 5}$ & $\mathbf{9 4 9 . 6 9 6 . 0 0 6 . 1 5 0 , 7 6}$ & $\mathbf{2 7 , 9 6 6}$ & $\mathbf{2 6 2 , 4 2 9}$ \\
\hline
\end{tabular}

Sumber : Data diolah, 2018

Berdasarkan Tabel 7 tersebut diketahui bahwa pada tahun 2008-2017 menunjukan persentase tingkat kemandirian yang terus meningkat kecuali pada tahun 2016 mengalami 
penurunan. Rasio kemandirian tertinggi yaitu pada tahun 2017 dikategorikan masih rendah dengan persentase sebesar 42,07 persen sebagaimana berdasarkan kriteria kinerja keuangan efektivitas keuangan daerah dimana 25-50 persen merupakan kriteria rendah. Sedangkan tingkat kemandirian terendah yaitu pada tahun 2008 sebesar 10,66 persen menurut kriteria tingkat kemandirian keuangan daerah 0-25 persen merupakan kriteria tingkat kemandirian sangat rendah. Dari tabel di atas dapat dibuat gambar rasio tingkat kemandirian keuangan daerah sebagai berikut:

\section{Gambar 2. Rasio Kemandirian dan Trend Kemandirian}

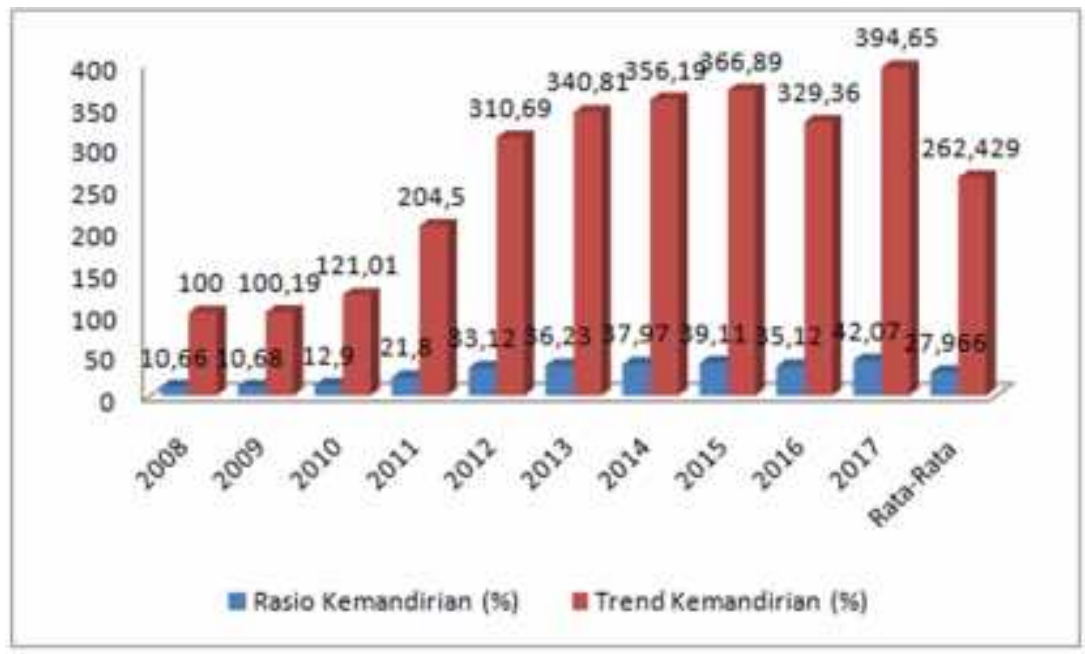

Sumber: Data diolah, 2018

Dari data di atas terlihat rata-rata kemandirian keuangan daerah Kota Bandar Lampung pada tahun 2008-2017 sebesar 27,966 persen dikategorikan rendah sebagaimana berdasarkan kriteria kinerja keuangan efektivitas keuangan daerah dimana 25-50 persen merupakan kriteria rendah.

Berdasarkan tabel 7 bahwa pendapatan asli daerah Kota Bandar Lampung semakin meningkat setiap tahunnya tetapi diikuti dengan dana berimbang atau transferan dari pemerintah pusat yang semakin meningkat juga setiap tahunnya sehingga Kota Bandar Lampung masih belum mandiri untuk membiayai sendiri segala kegiatan pemerintahannya.

Selain itu dapat diartikan bahwa tidak ada peningkatan secara signifikan dalam hal partisipasi masyarakat dalam pembangunan daerah, seperti dalam hal pembayaran pajak dan retribusi. Besarnya penerimaan pajak dan retribusi daerah sebenarnya menunjukkan pemerintah daerah mengandalkan penerimaan pajak sebagai sumber penerimaan PAD, yang nantinya digunakan untuk membiayai pembangunan daerah. Namun jika dilihat dari pajak dan retribusi daerah yang masih rendah dan dana barimbang yang semakin meningkat dari tahun ke tahun menunjukkan pemerintah Kota Bandar Lampung kurang yakin dapat menggali potensi daerahnya sehingga pendapatan asli daerah yang di anggarkan masih rendah.

\section{Analisis Rasio Desentralisasi}

Rasio Desentralisasi Fiskal dapat dihitung dengan cara membandingkan antara total pendapatan asli daerah (PAD) dengan total pendapatan daerah. Berdasarkan rasio desentralisasi fiskal keuangan daerah pemerintah Kota Bandar Lampung pada tahun 20082017 dapat dilihat pada Tabel 8 berikut: 
Tabel 8. Rasio Desentralisasi Keuangan Daerah

Kota Bandar Lampung Tahun 2008-2017

\begin{tabular}{|c|c|c|c|c|}
\hline Tahun & PAD (Rp) & $\begin{array}{c}\text { Total Pendapatan } \\
\text { Daerah (Rp) }\end{array}$ & $\begin{array}{c}\text { Rasio } \\
\text { Desentralisasi } \\
\text { Fiskal (\%) }\end{array}$ & $\begin{array}{c}\text { Trend } \\
\text { Desentralisasi } \\
\text { Fiskal(\%) }\end{array}$ \\
\hline 2008 & 67.661 .519 .021 .92 & $747.982 .275 .000,50$ & 9,05 & 100 \\
\hline 2009 & $70.432 .260 .003,19$ & $793.493 .023 .000,29$ & 8,88 & 98,12 \\
\hline 2010 & $86.692 .399 .700,41$ & $959.069 .382 .000,31$ & 9,04 & 99,89 \\
\hline 2011 & $162.818 .119 .556,88$ & $1.187 .871 .504 .156,20$ & 13,71 & 151,49 \\
\hline 2012 & $298.696 .062 .085,49$ & $1.459 .471 .856 .318,18$ & 20,47 & 226,19 \\
\hline 2013 & $360.698 .350 .131,88$ & $1.688 .412 .290 .739,88$ & 21,36 & 236,02 \\
\hline 2014 & $394.646 .889 .446,59$ & $1.836 .004 .647 .114,59$ & 21,49 & 237,46 \\
\hline 2015 & $397.547 .326 .856,39$ & $1.843 .540 .674 .593,39$ & 21,56 & 238,23 \\
\hline 2016 & $483.379 .398 .034,84$ & $2.057 .086 .652 .010,39$ & 23,50 & 259,67 \\
\hline 2017 & $612.809 .680 .623,87$ & $2.081 .420 .040 .685,32$ & 29,44 & 325,30 \\
\hline
\end{tabular}

Sumber: Data diolah, 2018

Berdasarkan Tabel 8 tersebut diketahui bahwa rasio desentralisasi fiskal Kota Bandar Lampung tertinggi pada tahun 2017 dengan tingkat persentase mencapai 29,44 persen. Bila dilihat berdasarkan kriteria desentralisasi fiskal, pada tahun 2017 berada pada persentase diatas 25 persen dikategorikan sedang. Sedangkan tahun 2009 merupakan persentase desentralisasi fiskal terendah dengan persentase sebesar 8,88 dikategorikan sangat kurang. Dari tabel di atas dapat dibuat gambar rasio tingkat kemandirian keuangan daerah sebagai berikut:

\section{Gambar 3. Rasio Desentralisasi dan Trend Desentralisasi}

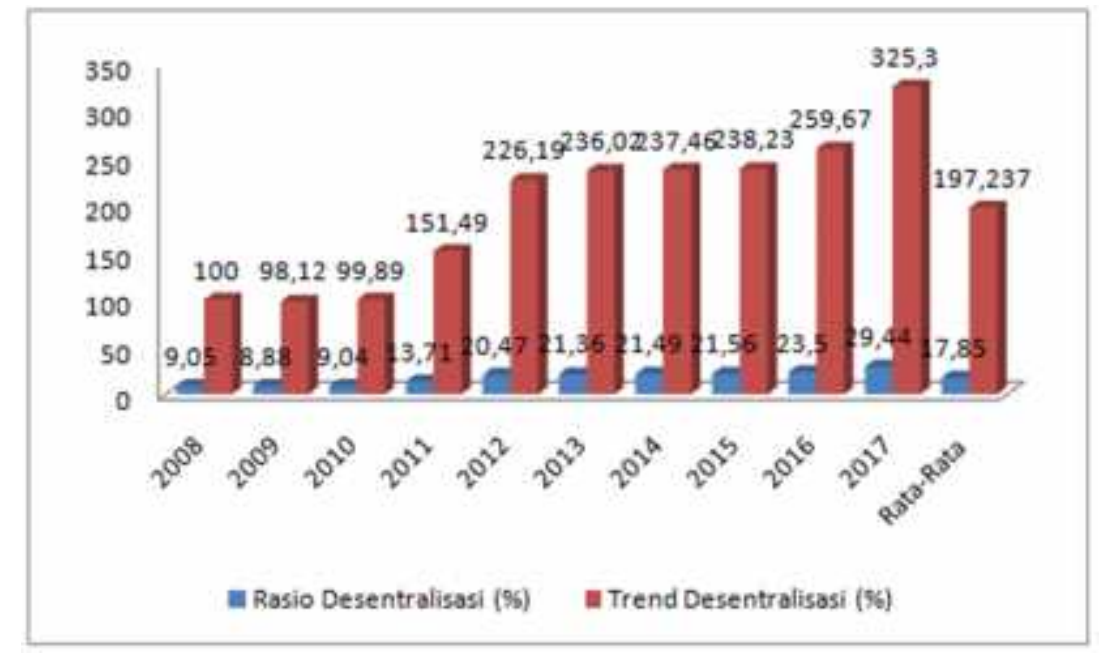

Sumber: Data diolah, 2018

Secara rata-rata kemampuan pemerintah daerah Kota Bandar Lampung dalam menjalankan kewenangan atau tanggung jawab yang diberikan pemerintah pusat masih kurang baik dengan persentase sebesar 17,85 persen. Sebagaimana berdasarkan kriteria desentralisasi fiskal keuangan daerah dimana dibawah 20,00 persen merupakan kriteria kurang baik.

Kurangnya kontribusi pendapatan asli daerah terhadap total pendapatan maka kurang juga kemampuan pemerintah daerah dalam menjalankan desentralisasi fiskal. Jumlah pendapatan asli daerah Kota Bandar Lampung dari tahun 2008-2017 memang terus mengalami peningkatan, akan tetapi kontribusi dana berimbang atau dana transferan dari 
pemerintah pusat juga mengalami peningkatan sehingga kembali mendominasi penerimaan pendapatan daerah. Yang artinya tingkat ketergantungan pemerintah Kota Bandar Lampung terhadap pemerintah pusat masih sangat tinggi.

Kinerja Kota Bandar Lampung belum maksimal walaupun setiap tahunnya Kota Bandar Lampung mencoba untuk menjadi lebih baik dalam pengelolaannya dan memperbaiki masalah-masalah diberbagai sektor seperti bagaimana memaksimalkan penerimaan pendapatan asli daerah, memaksimalkan penerimaan pendapatan asli daerah, memaksimalkan pengelolaan belanja daerah sehingga semua bisa terpanter karena Kota Bandar Lampung mengarah ke otonomi daerah. Dilihat dari trend desentralisasi fiskal keuangan daerah Kota Bandar Lampung selama periode tahun 2008-2017 menunjukan perkembangan yang semakin baik dengan persentase sebesar 197,237 persen dengan tahun dasar yaitu tahun 2008 sebesar 100 persen.

\section{KESIMPULAN}

Rasio efektivitas keuangan daerah pada pemerintah Kota Bandar Lampung selama tahun 2008-2017, pada tahun 2008, 2010, 2011, dan 2012 mampu mencapai persentase diatas 100 persen dengan kategori sangat efektif sedangkan 6 tahun lainnya belum mencapai persentase 100 persen. Hal ini dikarenakan belum tercapainya pendapatan asli daerah sesuai dengan target yang telah ditentukan. Secara rata-rata efektivitas keuangan daerah pada pemerintah Kota Bandar Lampung tahun 2008-2017 sudah efektif dengan persentase 90,495 persen dikategorikan efektif berdasarkan kriteria kemampuan efektivitas keuangan daerah. Jika dilihat berdasarkan trend rasio efektivitas mengalami kenaikan dan penurunan selama periode tahun 2008-2017 dengan rata-rata 70,814 persen sehingga dapat disimpulkan bahwa pemerintah Kota Bandar Lampung tidak mengalami perkembangan karena rata-rata trend efektivitas keuangan daerah tidak mencapai 100 persen.

Rasio kemandirian keuangan daerah pada pemerintah Kota Bandar Lampung tahun 2008-2017 mengalami kenaikan secara terus-menerus namun belum menunjukkan kemandirian yang semakin baik karena masih dalam kategori rendah dengan rata-rata sebesar 27,966 persen dikategorikan rendah karena nilai tersebut berada diantara 25-50 persen maka Kota Bandar Lampung dianggap masih sangat ketergantungan terhadap bantuan dari pemerintah pusat dan provinsi. Pemerintah Kota Bandar Lampung selalu berupaya mengurangi ketergantungan terhadap pemerintah pusat dan provinsi, hal ini terlihat dari trend kemandirian yang mengalami perkembangan selama periode tahun 2008-2018 karena rata-rata trend kemandirian keuangan daerah mencapai 100 persen dengan persentase sebesar 262,429 persen.

Rasio desentralisasi keuangan daerah pada pemerintah Kota Bandar Lampung selama periode tahun 2008-2017 cenderung mengalami peningkatan. secara rata-rata menunjukkan kemampuan pemerintah Kota Bandar Lampung dalam menjalankan kewenangan atau tanggung jawab yang diberikan oleh pemerintah pusat masih kurang baik yaitu sebesar 17,85 persen dikategorikan kurang berdasarkan kriteria desentralisasi keuangan daerah. Trend desentralisasi pemerintah Kota Bandar Lampung menunjukan kecenderungan peningkatan setiap tahunnya dengan rata-rata trend 197,237 persen yang artinya pemerintah Kota Bandar Lampung mengalami perkembangan dalam menjalankan kewenangan atau tanggung jawab yang diberikan oleh pemerintah pusat karena rata-rata trend desentralisasi keuangan daerah mencapai 100 persen. 
Hasil penelitian ini memberikan kontribusi bagi pemangku kepentingan khususnya kementerian keuangan dan pemerintah daerah. Dimana hasil penelitian bisa menjadi sumbangan pemikiran dalam menentukan kebijakan terkait keuangan daerah.

\section{E. DAFTAR PUSTAKA}

Adisasmita, Rahardjo. Pembiayaan Pembangunan Daerah. Yogyakarta: Graha Ilmu, 2011.

Aswarodi. "Analisis Perimbangan Keuangan Pusat Dan Daerah Sebelum Dan Setelah Pemberlakuan Undang -Undang No. 25 Tahun 1999 Di Kabupaten Lampung Selatan.” In Bunga Rampai Manajemen Keuangan Daerah. Yogyakarta: UPP AMP YKPN, 2004.

Badan Pusat Statistik Provinsi Lampung. Pendapatan Asli Daerah Kota Bandar Lampung 20082016, 2018.

Bisma, I Dewa Gde, and Susanto. "Evaluasi Kinerja Keuangan Daerah Pemerintah Provinsi Nusa Tenggara Barat Tahun Anggaran 2003-2007." Jurnal Ganec Swara 4, no. 3 (2010).

BPKAD. Laporan Keuangan Kota Bandar Lampung Tahun 2008-2017. Bandar Lampung, n.d.

Bratakusumah, Deddy Supriady. Otonomi Penyelenggaraaan Pemerintahan Daerah: Deddy Supriady Bratakusumah, Dadang Solihin. Gramedia Pustaka Utama, 2001.

Halim, Abdul. Akuntansi Keuangan Daerah. Jakarta: Salemba Empat, 2008.

Haryanto, Andri. Analisis Efektivitas, Kemandirian Dan Desentralisasi Pemerintah Kota Medan. Medan: Universitas Muhammadiyah Sumatera Utara, 2014.

Indonesia, Republik. "Undang-Undang Republik Indonesia Nomor 33 Tahun 2004 Tentang." Perimbangan Keuangan antara Pemerintah Pusat dan Pemerintah Daerah (2004).

Kemenkeu, DJPK. "Undang-Undang Nomor 34 Tahun 2000 Tentang Perubahan Pajak Atas Undang-Undang Republik Indonesia No.18 Tahun 1997 Tentang Pajak Dan Retribusi Daerah.” Lihat: Www.Djpk.Kemenkeu.Go.Id.

Maisyuri, Maisyuri. "Analisis Kinerja Keuangan Daerah Pemerintah Kota Lhokseumawe." Jurnal Visioner \& Strategis 6, no. 1 (2017).

Marizka, Reza. "Pengaruh Pendapatan Asli Daerah, Dana Bagi Hasil, Dana Alokasi Umum Dan Dana Alokasi Khusus Terhadap Tingkat Kemandirian Keuangan Daerah Pada Kabupaten Dan Kota Di Sumatera Barat (Tahun 2006-2011)." Jurnal Akuntansi 1, no. 3 (2013).

Mokodompit, Paramitha Sandy, Sifrid S Pangemanan, and Inggriani Elim. "Analisis Kinerja Keuangan Pemerintah Daerah Kota Kotamobagu." Jurnal EMBA: Jurnal Riset Ekonomi, Manajemen, Bisnis dan Akuntansi 2, no. 2 (2014).

Nomor, Keputusan Menteri Dalam Negeri. "Tahun 2002 Tentang Pedoman Pengurusan." Pertanggungjawaban Dan Pengawasan Keuangan Daerah Serta Tata Cara Penyusunan Anggaran Pendapatan Dan Belanja Daerah, Pelaksanaan Tata Usaha Keuangan Daerah Dan Penyusunan Perhitungan Anggaran Pendapatan Dan Belanja Daerah (29AD).

Pramono, Joko. "Analisis Rasio Keuangan Untuk Menilai Kinerja Keuangan Pemerintah Daerah (Studi Kasus Pada Pemerintah Kota Surakarta).” Among Makarti 7, no. 1 (2014).

Ratna, Ikhwani. “Analisis Kinerja Keuangan Daerah Dan Strategi Pembangunan Kota Di Era Otonomi Daerah Pada Kota Pekanbaru.” Jurnal El-Riyasah 3, no. 1 (2012).

Saputra, Dori. Analisis Kemandirian Dan Efektivitas Keuangan Daerah Pada Kabupaten Dan Kota Di Provinsi Sumatera Barat. Padang: Universitas Negeri Padang, 2014.

Sazali, Munawir. "Implementasi Pengelolaan Keuangan Negara Dalam Perspektif Ekonomi Islam (Studi APBN 2009-2017)." Al-Intaj: Jurnal Ekonomi dan Perbankan Syariah 6, no. 2 (2020). 